\title{
HEALTH BELIEF APPLICATION MODEL: KNOWLEDGE AND PATTERNS OF IRON SOURCE FOOD CONSUMPTION AS A PREVENTIVE EFFORT FOR ANEMIA EVENTS
}

\author{
Stefani Verona Indi Andani ${ }^{1}$, Trias Mahmudiono ${ }^{1}$, Yurike Dhika Adhela ${ }^{1}$ \\ ${ }^{1}$ Department of Nutrition, \\ Faculty of Public Health, Airlangga University, Surabaya, Indonesia \\ Correspondence address : Stefani Verona Indi Andani \\ E-mail : stefaniveronaindi@gmail.com
}

\begin{abstract}
Female adolescents are prone to iron deficiency anemia due to regular menstrual cycles and loss of basal, thus requiring sufficient iron intake from food consumed daily. The concept of the Health Belief Model which consists of perceived susceptibility, perceived severity, perceived benefit, perceived barrier, and self efficacy helps to take action on the prevention of anemia. This study aimed to analyze the correlation of knowledge, the Health Belief Model, and consumption patterns with anemic status at Saint Stanislaus High School. This study used a crosssectional design. The population in this study were all female students in grade X and XI of Saint Stanislaus Senior High School, totaling 84 people. The cluster random sampling technique was used to calculate the total amount of samples, totaling 46 people as the sample of this study. The data collected included respondent characteristics, knowledge rate, construction of Health Belief Model, consumption patterns of iron source foods differentiated into levels of adequacy and frequency of eating, and anemia status. The results of this study showed that 14 of the respondents aged 16 years experienced anemia (30.43\%). The correlation of knowledge and the incidence of anemia significantly correlated, with a p-value of 0.044 ( $\mathrm{p}$ <0.005). Meanwhile, constructs of the Health Belief Model and the level of adequacy of food consumption of iron sources had no correlation with the incidence of anemia ( $p>0.005)$. The frequency of kale consumption as a source of non heme iron had a correlation with the incidence of anemia ( $\mathrm{p}<0.005$ ). This study concluded that there was a correlation with knowledge and the incidence of anemia in Saint Stanislaus High School students. Proper nutrition education based on the concept of the Health Belief Model can be given to students to let them have an understanding, good attitude, and practice prevention measures for anemia well.
\end{abstract}

Keywords: knowledge, Health Belief Model, iron consumption pattern, anemic

\section{INTRODUCTION}

Anemia is a condition that occurs when red blood cell levels have a lower concentration than the body's physiological needs (Indonesian Ministry of Health, 2013). The World Health Organization (2010) states that the incidence of anemia in the world has reached $40-88 \%$, especially anemia that occurs in the group of adolescent girls in developing countries, which reached $53.7 \%$. In Indonesia, the prevalence of anemia still reached $21.7 \%$, with anemia at the age of 15-24 years reaching 18.4\% (Indonesian Ministry of Health, 2013). The group of young women experienced a loss of iron reaching $0.56 \mathrm{mg}$ per day during menstruation. The amount of basal iron loss reached $0.8 \mathrm{mg}$ per day, meaning the total iron loss was $1.36 \mathrm{mg}$ per day (Huffman et al., 2001). This automatically increases the need for iron to compensate for losses due to menstruation (Kristianti and Wibowo, 2013).

Most of the anemia problems experienced by young women are caused by iron deficiency. Arisman (2010) states that young women tend to go on a strict diet to maintain body shape, leading to irregular eating patterns which affect nutrient intake, especially iron (Syatriani and Aryani, 2010). Iron status in the body is also influenced by iron absorption factors consisting of enhancers (boosters) and inhibitors (inhibitors). Enhancer factors include vitamin $\mathrm{C}$ and animal protein 
sources. Inhibitor factors include caffeine, tannins, oxalate, and phytate (Herta, et al., 2013).

Another factor that affects the incidence of anemia is nutritional knowledge, which determines the ability to apply information about food needs and values in daily consumption (Suria, 2017). Nutritional knowledge is an understanding of food, its nutritional components, safe food for consumption, and appropriate processing methods to minimize the loss of nutritional content from these food ingredients (Suryani, et al., 2015). Coverage of iron consumption is positively related to the level of knowledge (Indonesian Ministry of Health, 2013). Low nutritional knowledge leads to incorrect food choices and can lead to iron deficiency anemia. Good nutritional knowledge can prevent anemia problems through the selection of the right food ingredients (Arisman, 2010).

The Health Belief Model (HBM) states that a person's behavior changes when there is an understanding that the health problem they are suffering from is serious (Becker et al., 1987). The behavior referred to in this study is the consumption pattern of iron-rich foods. The HBM theory was applied in this study as the main concept in taking measures to prevent anemia. HBM has a construct consisting of perceived susceptibility, perceived severity, perceived benefit, perceived barrier, and self efficacy (Contento, 2011).

The HBM theory is built through the belief that in shaping the expected behavior, a person is determined by the belief that he is prone to anemia problems, the belief that anemia is a serious health problem, the belief in the benefits obtained through prevention efforts, the belief in the existence of obstacles in seeking action for the prevention of anemia, and confidence in one's ability to seek preventive measures (Kurniawati and Sulistyowati, 2014). The researchers wanted to analyze the relationship between consumption patterns of iron sources, level of knowledge, and constructs of the HBM with the incidence of anemia.

\section{METHODS}

The study with a cross-sectional design was carried out at SMAK Santo Stanislaus Surabaya from April 2019 to May 2019. This school was chosen as a research location because there had never been a study related to behavior change based on the HBM to prevent and overcome anemia. This was especially true for the incidence of anemia, which was predicted to be high through a physical test before the implementation of the study. The research population was all students of class $\mathrm{X}$ and XI with a total of 84 students, all of which were divided into the MIPA class and IPS class. Samples were taken using simple random sampling method. This method was used to ensure that all students had the same opportunity to be selected as respondents in this study. Calculation of the sample was done using the Slovin formula with a population of 84 and an error rate of 0.1 ; the number of samples (n) was 46 students.

The samples selected in this study followed the established inclusion criteria, namely students in grades X and XI in the age range of 15-18 years, did not menstruate during a blood test to determine hemoglobin levels, and had regular menstrual cycles. Exclusion criteria included having blood disorders other than anemia, having other complications, not having menstruation, and currently following special nutritional interventions such as a low-iron diet from poultry, meat, fish, eggs and green vegetables sources. After being selected using these criteria, the sample was given an explanation of the research information to be carried out and signed a consent form to participate in the entire series of research.

The data collected include the level of knowledge about anemia and nutrition through a knowledge questionnaire. This included questions about perceived susceptibility, perceived severity, 
perceived benefit, perceived barrier, and self efficacy through the HBM questionnaire (likert scale), consumption patterns of iron sources through the Semi Quantitative Food Frequency Questionnaire (SQ-FFQ) and hemoglobin levels through a blood test using a digital hemoglobinometer (Easy Touch). Assessment of the knowledge questionnaire was done by giving a score of 1 for correct answers and a score of 0 for incorrect answers, then categorizing overall scores into less if the number of correct answers was $<60 \%$, sufficient if the number of correct answers reached $60-85 \%$, and good if the number of correct answers was $>85 \%$ (Candra, 2018). The assessment of the HBM construct questionnaire used the category of strongly disagree with a score of 1 , disagree with a score of 2 , neutral with a score of 3 , agree with a score of 4 , and strongly agree with a score of 5 (Ghaderi et al., 2017). The SQ-FFQ assessment was done by multiplying the frequency of consumption and the portion of food consumed in the last month. The data were analyzed using the Spearman rank correlation test to analyze the relationship between the level of knowledge, consumption patterns of iron sources, and the construct of the HBM with the anemia status of adolescent girls.

\section{RESULT}

\section{Sample Distribution Based on Various Characteristics}

Characteristics of respondents studied in this study included age, pocket money, education of the respondent's mother, respondent's family income, menstrual cycle, and duration of menstruation. According to the research data contained in Table 1, the data showed that out of a total of 46 respondents, the majority of respondents were 16 years old (47.9\%). The lowest age of respondents was 15 years old with as many as 10 people (20.8\%), while the highest age of respondents was 18 years with only one person $(2.1 \%)$. The incidence of anemia can be experienced at all ages (Dumilah and Sumarmi, 2017). Respondents' pocket money is money that was specifically spent on buying food when they were out of the house. When viewed in terms of pocket money, the majority of respondents had pocket money between Rp. 11,000 and Rp. 15,000 , namely as many as 12 respondents $(25 \%)$. Based on the distribution of respondent data, it can be seen that the majority of respondents' mothers had high school education, namely 15 respondents $(50 \%)$. Furthermore, when viewed from family income, which is the total income of the father and mother each month, the majority of respondents belonged to families with a large income of $\mathrm{Rp}$. $1,000,000$ to Rp. 5,000,000 (54.2\%).

Table 1. Sample Distribution Based on Various Characteristics

\begin{tabular}{|c|c|c|}
\hline Characteristic & Category & $\begin{array}{c}\text { Total } \\
(\%)\end{array}$ \\
\hline \multirow[t]{4}{*}{ Age } & 15 & $10(21.7)$ \\
\hline & 16 & $23(50)$ \\
\hline & 17 & $12(26.1)$ \\
\hline & 18 & $1(2.2)$ \\
\hline \multirow[t]{7}{*}{ Pocket money } & $\begin{array}{l}\text { Rp. } 2,500- \\
\text { Rp. } 5,000\end{array}$ & $2(4.4)$ \\
\hline & $\begin{array}{l}\text { Rp. } 6,000- \\
\text { Rp. } 10,000\end{array}$ & $11(23.9)$ \\
\hline & Rp. 11,000 & \\
\hline & ${ }_{15,000} \mathrm{Rp}$ & $12(26.1)$ \\
\hline & Rp. 16,000 & \\
\hline & ${ }_{20,000}$ Rp. & $11(23.9)$ \\
\hline & $\begin{array}{l}>\mathrm{Rp} . \\
20,000\end{array}$ & $10(21.7)$ \\
\hline \multirow{5}{*}{$\begin{array}{l}\text { Mother's } \\
\text { Education }\end{array}$} & No school & $1(2.2)$ \\
\hline & Elementary & $2(4.4)$ \\
\hline & $\begin{array}{l}\text { Junior high } \\
\text { school }\end{array}$ & $4(8.7)$ \\
\hline & $\begin{array}{l}\text { Senior High } \\
\text { School }\end{array}$ & $24(52.2)$ \\
\hline & Graduate & $15(32.6)$ \\
\hline Family income & $\begin{array}{l}\text { Rp. } \\
500,000 \quad-\end{array}$ & $5(10.4)$ \\
\hline
\end{tabular}




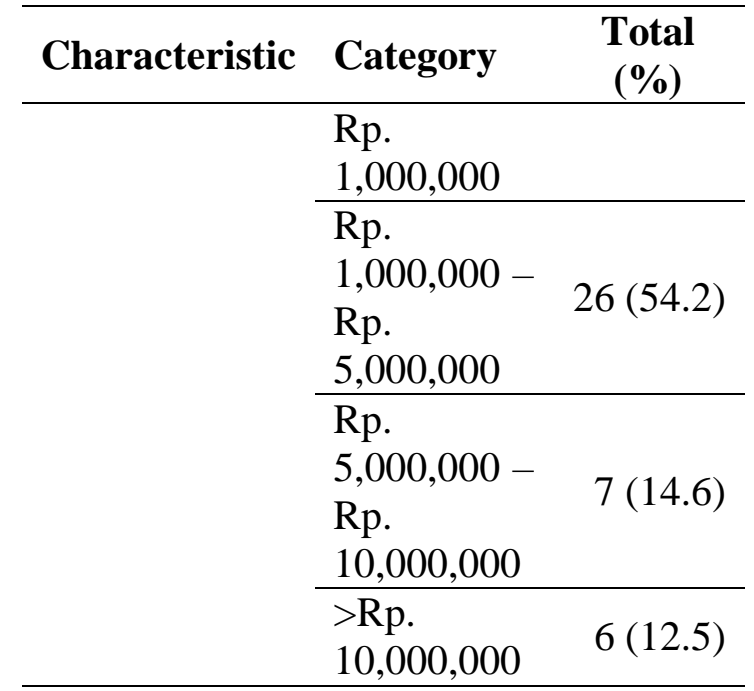

\section{Sample Knowledge Level Distribution}

The results of this study stated that in terms of respondents' knowledge about anemia and nutrition, 28 respondents $(60.9 \%)$ still had poor knowledge. Respondents were classified in the less category if the number of correct answers from the total questions did not reach $60 \%$. This value states the amount of knowledge the respondent has regarding the causes of anemia, the impact, and prevention and control that can be done through the consumption of adequate iron intake. Lack of knowledge can be caused by a lack of understanding and incomplete acceptance of information about anemia and nutrition (Mularsih, 2017). Lack of acceptance can be due to a lack of exposure to information about anemia and nutrition.

\section{Sample Distribution Based on the Health Belief Model}

The sample distribution in Table 2 shows that more than $50 \%$ of respondents belonged to the less category for the constructs of perceived susceptibility $(95.7 \%)$ and perceived severity $(89.1 \%)$. On the other hand, less than $50 \%$ of respondents belonged to the less category for perceived benefit (19.6\%), perceived barrier $(6.5 \%)$, and self efficacy $(58.7 \%)$. The concept of the HBM can explain preventive behavior conditional on certain belief patterns (Shahrabani and Benzion, 2012).

Table 2. Sample Distribution Based on the Health Belief Model

\begin{tabular}{|c|c|c|c|}
\hline $\begin{array}{c}\text { HBM } \\
\text { Construct }\end{array}$ & Category & $\mathbf{n}$ & $\%$ \\
\hline \multirow{2}{*}{$\begin{array}{l}\text { Perceived } \\
\text { susceptibility }\end{array}$} & $\begin{array}{l}\text { Less } \\
\text { vulnerable }\end{array}$ & 44 & 95.7 \\
\hline & $\begin{array}{l}\text { Quite } \\
\text { vulnerable }\end{array}$ & 2 & 4.3 \\
\hline \multirow{2}{*}{$\begin{array}{l}\text { Perceived } \\
\text { Severity }\end{array}$} & Less severe & 41 & 89.1 \\
\hline & $\begin{array}{l}\text { Severe } \\
\text { enough }\end{array}$ & 5 & 10.9 \\
\hline \multirow{2}{*}{$\begin{array}{l}\text { Perceived } \\
\text { Benefit }\end{array}$} & Less benefit & 9 & 19.6 \\
\hline & $\begin{array}{l}\text { Enough } \\
\text { benefit }\end{array}$ & 37 & 80.4 \\
\hline \multirow{2}{*}{$\begin{array}{l}\text { Perceived } \\
\text { Barrier }\end{array}$} & $\begin{array}{l}\text { Less } \\
\text { obstacles }\end{array}$ & 43 & 93.5 \\
\hline & $\begin{array}{l}\text { Enough } \\
\text { obstacles }\end{array}$ & 3 & 6.5 \\
\hline \multirow{3}{*}{ Self Efficacy } & Low & 19 & 41.3 \\
\hline & Tall & 27 & 58.7 \\
\hline & Total & 46 & 100 \\
\hline
\end{tabular}

Perceived susceptibility was assessed through instruments in the form of vulnerability due to biological conditions, monthly menstruation, as well as current body and health conditions. Perceived severity was assessed through instruments in the form of the severity caused by anemia through its impact on concentration, as well as losses and other long-term impacts. Perceived benefits were assessed through instruments in the form of benefits obtained through prevention of anemia by consuming iron-rich foods, increasing consumption of enhancers, and reducing consumption of inhibitors, as well as consumption of blood-added tablets. Perceived barriers were assessed through instruments in the form of perceived barriers in carrying out the anemia prevention behavior. Self-efficacy or confidence in one's ability to prevent anemia was assessed through an instrument in the form of a statement of the level of difficulty or ease of self. A person has their own belief in the level of vulnerability and 
severity, which affects their encouragement in taking preventive efforts.

\section{Distribution Based on Consumption Patterns of Iron Source Foods}

Iron intake is an important marker in the occurrence of anemia because iron has a relationship with hemoglobin levels. Iron is the main constituent component that has an important role in the process of forming blood cells, especially hemoglobin. Sufficient iron stores will meet the needs of the red blood cell formation process in the bone marrow. Conversely, if the amount of iron stores is reduced and the intake of iron is low, it can disrupt the balance of iron in the body, causing hemoglobin levels to decrease, and iron nutritional anemia occurs (Bakta, 2007). In fact, the iron needs of adolescent girls actually increase due to menstrual conditions, which are the cause of iron loss (Muchlisa, et al., 2013). In Table 3 of this study, it appears that $87 \%$ of respondents were still classified as lacking in their consumption of iron sources because they were still below $77 \%$ of the requirement. According to the Nutritional Adequacy Ratio, adolescents aged 16-18 years must consume $26 \mathrm{mg}$ of iron.

Table 3. Distribution of Samples Based on Adequacy Level of Consumption of Food Sources of Iron

\begin{tabular}{ccc}
\hline Category & n & \% \\
\hline Less $(<77 \% \mathrm{AKG})$ & 40 & 87 \\
Adequate $(\geq 77 \% \mathrm{AKG})$ & 6 & 13 \\
Total & 46 & 100 \\
\hline
\end{tabular}

Sources of iron consumed are divided into sources of heme iron derived from animal foods and non-heme iron sources derived from plant foods. Heme iron cannot be found anywhere other than animal foods because it comes from hemoglobin and myoglobin, with a bioavailability of $20 \%-30 \%$. This makes heme iron more easily absorbed by the body and is not influenced by other foods consumed. It is only slightly affected by the iron status of the person consuming it (Brooker, 2001). On the other hand, nonheme iron in its absorption is very easily influenced by enhancer and inhibitor factors from the food consumed. The absorption was only found to be $5 \%$ for the body.

Table 4 shows the frequency of consumption of food sources of heme and non-heme iron that were often consumed by respondents. The frequency of eating was divided into less than two times per week and more than or equal to 2 times per week. The results showed that the type of food source of heme iron that was often consumed ( $\geq 2$ times per week) was consumed by more than half of the respondents $(65.2 \%)$, namely chicken meat, followed by chicken eggs $(56.5 \%)$. While beef liver was consumed the least $(<2$ times per week) by respondents and only a few frequently consumed it $(2.2 \%)$. This could be because chicken meat is relatively abundant, easy to find both in markets and in supermarkets, and its price is relatively inexpensive. This also applies to the consumption pattern of tempeh and tofu, which are the types of non-heme iron sources consumed by more than half of the respondents $(76.1 \%)$ with frequent frequency. Tempeh and tofu are sources of non-heme iron that have abundant availability both in markets and supermarkets. The price of these foodstuffs is very affordable and they are easily accessible to many people.

Table 4. Distribution of Samples by Frequency of Consumption

\begin{tabular}{lcc}
\hline \multirow{2}{*}{ Food material } & \multicolumn{2}{c}{$\begin{array}{c}\text { Feeding Frequency } \\
\text { (weekly) }\end{array}$} \\
\cline { 2 - 3 } & $\mathbf{2 \times}(\mathbf{\%})$ & $\mathbf{2 x ( \% )}$ \\
\hline Heme Iron & & \\
\hline Beef & $23(50)$ & $23(50)$ \\
\hline Beef liver & $45(97.8)$ & $1(2.2)$ \\
\hline Lamb & $43(93.5)$ & $3(6.5)$ \\
\hline Chicken meat & $16(34.8)$ & $30(65.2)$ \\
\hline Chicken liver & $42(91.3)$ & $4(8.7)$ \\
\hline
\end{tabular}




\begin{tabular}{|c|c|c|}
\hline \multirow[t]{2}{*}{ Food material } & \multicolumn{2}{|c|}{$\begin{array}{c}\text { Feeding Frequency } \\
\text { (weekly) }\end{array}$} \\
\hline & $<2 \times(\%)$ & $\geq 2 \times(\%)$ \\
\hline Chicken eggs & $20(43.5)$ & $26(56.5)$ \\
\hline Milkfish & $36(78.3)$ & $10(21.7)$ \\
\hline Shrimp & $23(50)$ & $23(50)$ \\
\hline \multicolumn{3}{|l|}{ Non-Heme Iron } \\
\hline Know & $11(23.9)$ & $35(76.1)$ \\
\hline Tempe & $11(23.9)$ & $35(76.1)$ \\
\hline Long beal & $36(78.3)$ & $10(21.7)$ \\
\hline Spinach & $34(73.9)$ & $12(26.1)$ \\
\hline Cassava leaves & $42(91.3)$ & $4(8.7)$ \\
\hline Moringa & $42(91.3)$ & $4(8.7)$ \\
\hline Spinach & $25(54.3)$ & $21(45.7)$ \\
\hline Mung beans & $40(87)$ & $6(13)$ \\
\hline
\end{tabular}

\section{Relationship Between Knowledge Level and Anemia Incidence}

Table 5. Relationship of Knowledge Level with Anemia Status

\begin{tabular}{lccccc}
\hline Category & \multicolumn{3}{c}{ Anemia Status } & P- \\
\cline { 2 - 5 } & \multicolumn{2}{c}{ Anemia } & \multicolumn{2}{c}{$\begin{array}{l}\text { Not } \\
\text { Value }\end{array}$} \\
\cline { 2 - 5 } & & & Anemia & \\
\hline Less & 8 & 57.1 & 20 & 62.5 & \\
\hline Adequate & 6 & 42.9 & 12 & 37.5 & 0.044 \\
\hline Well & 0 & 0 & 0 & 0 & \\
\hline
\end{tabular}

The research results listed in Table 5 state that the Pearson Product Moment test resulted in a p-value of 0.044 (p $<0.005$ ), which means that there was a relationship between the level of knowledge and the incidence of anemia in SMAK Santo Stanislaus students. Knowledge can be the basis for a person to behave in a more durable manner (Notoatmodjo, 2012). Respondents' knowledge about nutrition and anemia in this study included an understanding of the term anemia, the definition of anemia, the causes of anemia, signs and symptoms of anemia, the consequences of anemia experienced, who is at risk for anemia, the mechanism of anemia, how to prevent anemia by consuming food, sources of iron, as well as factors that affect iron absorption, how to treat anemia, Hb levels, and food sources of iron.

\section{The Relationship Between the Health Belief Model and the Incidence of Anemia}

The Health Belief Model, which later became one of the variables in this study, can be seen in Table 6. Perceived susceptibility refers to a person's belief about the risk of suffering from a disease or things that interfere with health (Contento, 2011). The results of the Pearson Product Moment test with a value of 0.05 indicated a p-value of 0.572 for perceived susceptibility. This indicates that there was no relationship between perceived susceptibility and the incidence of anemia in SMAK Santo Stanislaus students. The perceived severity construct refers to a person's feelings about the seriousness of suffering from a disease, including the consequences medical and social consequences (Brooker, 2001). The results of the Pearson Product Moment test had a value of 0.05 and indicated a p-value of 0.816 for perceived severity. This indicates that there was no relationship between perceived severity and the incidence of anemia in respondents. Perceived benefit refers to a person's belief about the benefits of disease prevention measures (Rosenstock, 1974). The results of the Pearson Product Moment test had a value of 0.05 and indicated a p-value of 0.067 for perceived benefit. This indicates that there was no relationship between perceived benefit and the incidence of anemia in respondents. The results of the Pearson Product Moment test had a value of 0.05 and indicated a p-value of 0.981 for the perceived barrier. This indicates that there was no relationship between the perceived barrier and the incidence of anemia in respondents. The results of the Pearson Product Moment test had a value of $=0.05$ and indicated a p-value of 0.236 for selfefficacy. This indicates that there was no relationship between self-efficacy and the incidence of anemia in respondents. 
Table 6. The Relationship of the Health Belief Model with Anemia Status

\begin{tabular}{|c|c|c|c|c|}
\hline \multirow[b]{2}{*}{ Characteristic } & \multirow[b]{2}{*}{ Category } & \multicolumn{2}{|c|}{ Anemia Status } & \multirow[b]{2}{*}{ P-Value } \\
\hline & & Anemia (\%) & $\begin{array}{c}\text { No Anemia } \\
(\%)\end{array}$ & \\
\hline \multirow{2}{*}{$\begin{array}{l}\text { Perceived } \\
\text { Susceptibility }\end{array}$} & Less vulnerable & $13(92.9)$ & $31(96.9)$ & \multirow{2}{*}{0.572} \\
\hline & quite vulnerable & $1(7.1)$ & $1(3.1)$ & \\
\hline \multirow{2}{*}{$\begin{array}{l}\text { Perceived } \\
\text { Severity }\end{array}$} & Less severe & $13(92.9)$ & $28(87.5)$ & \multirow{2}{*}{0.816} \\
\hline & Severe enough & $1(7.1)$ & $4(12.5)$ & \\
\hline \multirow{2}{*}{$\begin{array}{l}\text { Perceived } \\
\text { Benefit }\end{array}$} & Less benefit & $1(7.1)$ & $8(25)$ & \multirow{2}{*}{0.067} \\
\hline & Enough benefit & $13(92.9)$ & $24(75)$ & \\
\hline \multirow[b]{2}{*}{$\begin{array}{l}\text { Perceived } \\
\text { Barrier }\end{array}$} & Less obstacles & $13(92.9)$ & $30(93.8)$ & \multirow[b]{2}{*}{0.981} \\
\hline & $\begin{array}{l}\text { Enough } \\
\text { obstacles }\end{array}$ & $1(7.1)$ & $2(6.2)$ & \\
\hline \multirow{2}{*}{ Self efficacy } & Low & $5(35.7)$ & $14(43.8)$ & \multirow{2}{*}{0.236} \\
\hline & Tall & $9(64.3)$ & $18(56.2)$ & \\
\hline
\end{tabular}

\section{Relationship Between Consumption Patterns of Iron-Rich Foods and Anemia}

The results of the cross tabulation stated that there were 13 respondents (92.9\%). The results of the Spearman test with a value of 0.05 showed a $p$-value of 0.416 ( $p>0.05$ ), which means that there was no significant relationship between the level of iron adequacy and the incidence of anemia in respondents. There was a relationship between the frequency of consumption of kale with the incidence of anemia. Kangkung is a source of non-heme iron which has an iron content of $2.5 \mathrm{mg}$ per 100 grams of kale (Almatsier, 2010).

\section{DISCUSSION}

\section{Sample Distribution Based on Various Characteristics}

In this study, respondents belonged to the age range of 16 to 18 years, which is the fertile age for a woman. Women of childbearing age (WUS) are classified as susceptible to anemia. According to Riskesdas (2013), the prevalence of anemia in women of childbearing age (WUS) between 15 to 44 years reached $35.3 \%$. The amount of pocket money to buy food outside can be influenced by parents' income (Astuti and Trisna (2016). Lower parental income can limit the amount of pocket money given to children. This of course affects the purchase of food in the school environment, such as snacks. The nutritional composition of ringworm is less concerned with nutritional composition. Of course, it affects the intake of iron from these foods to meet the body's needs. The results of the study found that the number of respondents within the moderate pocket money group had the highest number, in line with the income of parents in the middle class.

The mother's education is the main capital in fulfilling family nutritional intake and supporting the family financially. This is in accordance with the theory of Permaesih (2005), which states that education affects the choice of food consumed. With a higher education, a person has better knowledge and information about nutrition because it is easier to receive the health information, especially about nutrition. 


\section{Distribution of Samples Based on Consumption Patterns of Food Sources of Iron}

In this study, the average respondent was still unable to meet iron needs through consumption patterns of iron-rich foods. Iron intake is an important marker in the occurrence of anemia because iron has a relationship with hemoglobin levels. Iron is the main constituent component that has an important role in the process of forming blood cells, especially hemoglobin. Sufficient iron stores will meet the needs of the red blood cell formation process in the bone marrow. Conversely, if the amount of iron stores is reduced and the intake of iron is low, it can disrupt the balance of iron in the body, causing hemoglobin levels to decrease, and iron nutritional anemia occurs (Bakta, 2006). In fact, the iron needs of adolescent girls actually increase due to menstrual conditions, which are the cause of iron loss (Muchlisa, et al., 2013).

\section{Relationship Between Knowledge Level and Anemia Incidence}

Based on the results of the study, anemia experienced by respondents was mostly found in respondents with a low level of knowledge. Tenri Yamin (2012) also found that adolescents with less knowledge had a higher incidence of anemia than adolescents with good knowledge. Knowledge is one of the factors that influence the incidence of anemia. A good level of knowledge among teenagers can affect their hemoglobin levels (Khomsan, 2003). The existence of knowledge about the benefits of something can encourage someone to have a positive attitude towards it. Knowledge about anemia greatly affects the tendency of adolescents to choose foods with high nutritional value, especially those containing high iron (Caturiyantiningtiyas, 2015). Armed with good knowledge about anemia, it can minimize the selection of food and beverage ingredients that can inhibit the absorption of iron. This is in line with the research conducted by Listiana (2016), which found that there was a significant relationship between the level of knowledge and the incidence of anemia in adolescent girls. Knowledge can be a protective factor that can minimize the incidence of anemia. Knowledge can be used to change people's behavior, especially in encouraging young women to eat healthy and nutritious food. However, it cannot be denied that with sufficient knowledge, there is still a tendency for the incidence of anemia in adolescent girls (Caturiyantiningtiyas, 2015).

\section{The Relationship Between Health Belief Model and the Incidence of Anemia}

In this study, there was no significant relationship between all components of the HBM which consisted of perceived vulnerability, perceived severity, perceived benefits, perceived barriers, and self-confidence. The concept of perceived vulnerability occurs when someone who believes that he or she is at low risk of developing a disease will certainly find it easier to engage in unhealthy behavior and vice versa. Meanwhile, someone who believes that he or she is at high risk it will be easier to encourage someone to pursue healthy behavior and reduce the risk of suffering a disease (Onoruoiza et al., 2015). Other studies state that perceived susceptibility has a strong relationship with healthy living behavior. Courtenay (1998) mentions that this does not always occur.

In this study, there was no relationship between the HBM construct and the incidence of anemia. The results of the study stated that the less susceptible a person feels to anemia, the more the incidence of anemia experienced. This may be due to the absence of conscious behavior in preventing the occurrence of anemia, for example in increasing consumption patterns of foods rich in iron content. Anemia prevention measures are carried out by increasing the consumption pattern of ironrich foods to prevent anemia. This can happen because the knowledge that 
respondents have about anemia was still relatively lacking. If someone understands and knows anemia well, then they will feel more vulnerable to anemia, thus leading to preventive behavior (Ghaderi et al., 2017). This also affects other HBM constructs such as perceived severity, perceived benefits, perceived barriers, and self-confidence due to low levels of knowledge.

\section{The Relationship of the Pattern of Consumption of Iron Source Foods with the Incidence of Anemia}

The results of this study stated that there was no significant relationship between the level of adequacy of consumption of iron-rich foods and the incidence of anemia in the sample. This has similarities with research conducted by Fitrah, et al. (2011), which states that there is no relationship between iron intake and hemoglobin levels. Iron intake can be an important marker of anemia because iron has a relationship with hemoglobin levels. Iron stores with sufficient amounts in the body can encourage the process of formation of red blood cells that occurs in the bone marrow. If iron stores in the body are lacking due to lack of intake, then depletion will gradually occur.

The iron depletion process is divided into three stages with varying degrees of severity, from mild to severe. The first stage is a decrease in iron stores with a marked decrease in serum ferritin levels. The second stage has biochemical changes that indicate a lack of iron to produce normal amounts of hemoglobin. The third stage is anemic status due to iron deficiency with hemoglobin levels that are less than $7 \mathrm{~g} / \mathrm{dl}$ (Arisman, 2010). In this study, the majority of samples had insufficient iron (86.95\%). The low consumption pattern of iron-rich foods leads to a greater percentage of iron intake that is lacking (Matayane, et al., 2014).

Iron intake and hemoglobin levels did not have a significant relationship in this study because it was possible that the respondents were still in the second stage.
In this stage, the possibility of anemia is present but is normochromic normocytic or classified as very mild, and there is a decrease in serum iron and transferrin saturation. Low iron intake causes disruption of the process of blood cell formation. Some of the plasma is sent to the bone marrow and functions in helping the formation of hemoglobin, while the other part is circulated throughout the body's tissues. Iron is also stored as body reserves in the form of ferritin which binds to proteins located in the liver, bile, muscles, and bone marrow. In conditions when iron intake from food is low, ferritin will be used in the hemoglobin production process. As a result, serum ferritin changes first and hemoglobin becomes the last marker of a person's anemia status (Fitrah et al., 2011). The presence of iron deficiency can be resolved through changes in eating habits, especially through increasing iron intake from foods with a high level of bioavailability (Muchlisa, et al., 2013).

When viewed from the distribution of respondents' consumption related to the type of food source of iron, the sample most often consumed was chicken meat, which is a type of heme iron. The total respondents who consumed chicken meat two times per week or more was 30 people $(65.22 \%)$. However, the results of the Spearman statistical test showed that among all foods rich in heme iron, none of them had a significant relationship with the incidence of anemia ( $p>0.005)$. This may be because the majority of respondents' intakes were still relatively low, as well as the possibility of consuming other types of food ingredients that are rich in heme iron. Likewise with the consumption of foods rich in non-heme iron, of all types of food only kale was associated with the incidence of anemia in the sample $(p<0.005)$. The types of non-heme iron-rich foods that were most often consumed were tofu and tempeh with a total of 35 respondents consuming them two or more times a week (76.08\%). The results of the Spearman statistical test showed that among the food sources of 
heme iron, none of them were significantly associated with the incidence of anemia ( $p$ $>0.005)$. This may be because the majority of respondents' intakes were still relatively low.

\section{CONCLUSION}

Based on the results of the study, it can be concluded that there was a significant relationship between the level of knowledge and the incidence of anemia in students of SMAK Santo Stanislaus Surabaya. The study stated that there was no relationship between the constructs of the HBM and the incidence of anemia and there was no relationship between the level of iron adequacy and the incidence of anemia in the sample. In particular, there was a relationship between consumption of nonheme iron sources, namely kale, and the incidence of anemia. Good knowledge can be a preventive measure for anemia, but this needs to be accompanied by attitudes and actions to prevent anemia through the belief that anemia is a problem that can occur and reach severity. This is in addition to selfconfidence that a person is able to prevent anemia through changes in consumption patterns of iron-rich foods. As an effort to prevent and control anemia, students need to receive more extensive nutrition education based on the HBM.

\section{REFERENCE}

Almatsier, S. (2010) Ilmu Gizi Dasar. Jakarta: PT Gramedia Pusaka. doi: 10.26911/thejhpb.2016.01.03.03.

Arisman, M. B. (2010) Gizi dalam Daur Kehidupan: Buku Ajar Ilmu Gizi. Jakarta: EGC.

Bakta, I. M. (2006) Pendekatan terhadap pasien Anemia Buku Ajar Penyakit Dalam IV. Jakarta: Pusat Penerbitan Ilmu Penyakit Dalam FK UI.

Bakta, I. M. (2007) Hematologi Klinis Ringkas. Jakarta: ECG.

Brooker, C. (2001) Kamus Saku Keperawatan. Jakarta: EGC.
Candra, A. (2018) "Faktor-faktor yang Memengaruhi Hasil Suplementasi Besi pada Ibu Hamil," Journal of Nutrition and Health, 6(2), hal. 6573.

Caturiyantiningtiyas, T. (2015) Hubungan Antara Pengetahuan, Sikap dan Perilaku dengan Kejadian Anemia Remaja utri X dan XI SMA Negeri 1 Polokarto.

Universitas

Muhammadiyah Surakarta. doi: 10.2752/174967810X126572452052 60.

Contento, R. I. (2011) Nutrition Education: Linking Research, Theory and Practice 2nd Edition. Kanada: Jones and Bartlett Publishers.

Dumilah, R. A. P. dan Sumarmi, S. (2017) "Hubungan kejadian Anemia dengan Prestasi Belajar Siswi di SMP Unggulan Bina Insani," Amerta Nutrition, 1(4), hal. 331-340. doi: 10.20473/amnt.v1.i4.2017.331-340.

Fitrah, E., Hadju, V. dan Citrakesumasari (2011) "Pola Konsumsi dan Status $\mathrm{Hb}$ Remaja Putri (SMP) di Daerah Endemik Malaria Kecamatan Baras Kabupaten Mamju Utara Sulawesi Barat," Jurnal MKMI, 7(1), hal. 6168.

Ghaderi, N. et al. (2017) "Effect of Education Based on the Health Belief Model (HBM) on Anemia Preventive Behaviors among Iranian Girl Students," International Journal of Pediaetrics, 5(42), hal. 5043-5052. doi: 10.22038/ijp.2017.22051.1844.

Herta, M., Yuli, L. dan Yuliana, D. P. (2013) "Pola Konsumsi (Faktor Inhibitor Dan Enhancer Fe) Terhadap Status Anemia Remaja Putri," Jurnal Kesehatan Masyarakat, 8(2), hal. 113-120. doi: 10.15294/kemas.v11i1.3516.

Huffman, L. S. et al. (2001) Essential Health Sector Actions to Improve Maternal Nutrition in Africa. Washington DC: The Linkages Project Academy for Educational Development. 
Indonesian Ministry of Health (2013) "Riset Kesehatan Dasar," Jakarta: Badan Penelitian dan Pengembangan Kesehatan Departemen Kesehatan Republik Indonesia. doi: 10.1007/s13398-014-0173-7.2.

Khomsan, A. (2003) Pangan dan Gizi untuk Kesehatan. Jakarta: PT. Raja Grafindo Persada.

Kristianti, S. dan Wibowo, T. A. (2013) "Hubungan Anemia dengan Siklus Menstruasi pada Remaja Putri di SMA Negeri 1 Imogiri, Bantul, Yogyakarta," Jurnal Studi Pemuda, 3(1), hal. 33-38.

Kurniawati, C. dan Sulistyowati, M. (2014) “Aplikasi Teori Health Belief Model dalam Pencegahan Keputihan Patologis," Jurnal Promosi kesehatan, Vol. 2(No. 2), hal. 117127.

Listiana, A. (2016) "Analisis Faktor-Faktor yang Berhubungan Dengan Kejadian Anemia Gizi Besi pada Remaja Putri di SMKN 1 Terbanggi Besar Lampung Tengah," Jurnal Kesehatan, 7(3), hal. 455-469. doi: 10.26630/jk.v7i3.230.

Matayane, S. G., Bolang, A. S. L. dan Kawengian, shirley E. S. (2014) "Hubungan Antara Asupan Protein dan Zat Besi dengan Kadar Hemoglobin Mahasiswa Program Studi Pendidikan Dokter Angkatan 2013 Fakultas Kedokteran Universitas Sam Ratulangi," Jurnal eBiomedik (eBm), 2(3).

Muchlisa, Citrakesumasari dan Indriasari, R. (2013) "Hubungan Asupan Zat Gizi dengan Status Gizi pada Remaja Putri di Fakultas Kesehatan Masyarakat Universitas Hasanuddin Makassar Tahun 2013," Jurnal MKMI, hal. 1-15.

Mularsih, S. (2017) "Hubungan
Pengetahuan Remaja Putri tentang Anemia dengan Perilaku Pencegahan Anemia pada saat Menstruasi di SMK Nusa Bhakti Kota Semarang," Jurnal Kebidanan, 6(2), hal. 80-85.

Notoatmodjo, S. (2012) Promosi Kesehatan: Teori dan Aplikasi. Jakarta: Rineka Cipta.

Onoruoiza, S. I. et al. (2015) "Using Health Belief Model as an Intervention to Non Compliance with Hypertension Information among Hypertensive Patient. International Organization of Scientific Research," Journal of Humanities and Social Science, 20(9), hal. 11-16. doi: 10.9790/083720951116.

Shahrabani, S. dan Benzion, U. (2012) "How Experience Shapes Health Beliefs: The Case of Influenza Vaccination," Health Education and Behavior, 39(5), hal. 612-619. doi: 10.1177/1090198111427411.

Suria, N. R. (2017) Hubungan antara Pengetahuan tentang Anemia, Tingkat Konsumsi Protein, Zat Besi dan Vitamin $C$ dengan Kadar Hemoglobin pada Siswa Sekolah Menengah Atas di SMAN 3 Ponorogo. Universitas Muhammadiyah Surakarta.

Suryani, D., Hafiani, R. dan Junita, R. (2015) "Analisis Pola Makan dan ANemia Gizi Besi pada Remaja Putri Kota Bengkulu," Jurnal Kesehatan Masyarakat Andalas, 10(1), hal. 1118. doi: 10.24893/jkma.10.1.1118.2015.

Syatriani, S. dan Aryani, A. (2010) "Konsumsi Makanan dan Kejadian Anemia pada Siswi Salah Satu SMP di Kota Makassar," Jurnal Kesehatan Masyarakat Nasional, 4(6), hal. 251254. doi: 10.21109/kesmas.v4i6.163. 